\title{
'Leadership is a sacred matter': women leaders contesting and contextualising neoliberal meritocracy in the Indonesian academia
}

Teguh Wijaya Mulya (iD ${ }^{a}$ and Zulfa Sakhiyya (iD ${ }^{b}$

${ }^{a}$ Faculty of Psychology, University of Surabaya, Surabaya, Indonesia; ${ }^{b}$ Faculty of Languages and Arts, Universitas Negeri Semarang, Semarang, Indonesia

\section{ABSTRACT}

Feminist scholars have critiqued neoliberal meritocracy as discriminating against female academics through the persistence of gender-biased assumptions, closed procedures of recruitment and promotion, and patriarchal network connections. While these scholars demand fairer meritocratic competition, we explore possibilities to (re)imagine academic career and university leadership beyond the dominant discourse of neoliberal meritocracy. Based on interviews with female deans in Indonesian universities, we identified two alternative discourses (in)forming their subjectivity as university leaders, which may both challenge and contextualise neoliberal meritocracy. The first is the Islamic notion of leadership as amanah (God-given responsibility), and the second is a view of university as family. We demonstrate that understanding university leadership through these discourses enables and fosters a sense of trust, nurture, harmony, relationality, and spirituality; which are in contrast with neoliberal meritocracy's objectivism, individualism, corporatism, and entrepreneurialism. Nevertheless, neoliberal meritocracy is quick to co-opt these contextual ways of being for its neoliberal agenda.

\section{ARTICLE HISTORY}

Received 7 November 2019

Accepted 17 July 2020

\section{KEYWORDS}

Gender; university leadership; meritocracy; neoliberalism; amanah; Indonesia

\section{Introduction}

Scientific reviews on gender and leadership have identified that women, as compared to men, are the more effective twenty-first-century leaders; they tend to be more democratic, participative, transformational, communal, and against unethical decisions (Gipson et al. 2017; Goethals and Hoyt 2017). In spite of these findings, women are still considerably under-represented in political and corporate leadership (Carli 2015), as well as in higher education (HE) settings (Fitzgerald 2012; Sakhiyya and Locke 2019). Statistics on women in universities - which are often regarded as the institution of science, neutral and objective in its pursuit of knowledge and self-management - still display a degree of glass ceiling phenomenon vis-a-vis women's career advancements and leadership roles (Blackmore and Sawers 2015; Johnson 2017). Hiding behind the notion of meritocracy, universities have been documented discriminating against women through the persistence of 
gender-biased assumptions, closed procedures of recruitment and promotion, and patriarchal network connections in various stages of career development (Bagilhole and Goode 2001; Brabazon and Schulz 2018; Howson, Kandiko, and de St Croix 2018; Locke and Wright 2017; Nielsen 2016; Brink and Yvonne 2012). These scholars called for the dismantling of structural barriers, a fairer playing field, transparent procedures, continuous oversight, gender balanced committees, stronger women networks and sponsorships, and a redefinition of what 'merit' means, such as an appreciation for teaching, administrative, and emotional work.

Traditionally promoted in the language of 'equal opportunity','disinterestedness', or 'no preferential treatment', meritocracy - a system where individuals are fairly given opportunity and rewarded based on their merits and efforts (Scully 1997) - has somewhat transformed in response to the contemporary neoliberal contexts or what Au (2016) calls Meritocracy 2.0. The new feature involves a 'sheer extent of its attempts to atomise people as individuals who must compete with each other to succeed, by extending entrepreneurial behaviour into the nooks and crannies of everyday life' (Littler 2018, 2). Ignoring socio-economic inequalities, meritocratic logic individualises and depoliticises the problems; individuals self-judge, self-blame, and self-help themselves (Au 2016; Nikunen 2012). As universities become increasingly corporatised, marketised, and audited (Wijaya Mulya 2019), neoliberal meritocracy encourages academics to not only be individualistic, but also enterprising, self-promoting, and pursuing competitive success (Bagilhole and Goode 2001; Littler 2018). Simultaneously, neoliberal meritocracy reduces the meaningfulness of academic work (Howson, Kandiko, and de St Croix 2018) into a competitive entrepreneurial game for recognition, power, status, and money. It is within these dominant neoliberal meritocratic discourses that the notions of contemporary academics and university leadership are constituted and reproduced.

Extending aforementioned studies that have demonstrated how current practices of meritocracy in universities have resulted in discrimination, the current article seeks to explore a new conceptual trajectory by contesting the discourse of neoliberal meritocracy itself in understanding university leadership. Rather than demanding a fairer competition, we (re)imagine how to think about academic career advancement and university leadership without neoliberal meritocracy. What alternative discourses may we draw upon in giving new meaning to university leadership and academic career - which is fair, viable, and intelligible for twenty-first-century academia?

To this end, we build upon Sakhiyya and Rata's (2019) insights on the shift of the value of knowledge in $\mathrm{HE}$, namely, from 'priceless' to 'priced'. They argued that a fundamental shift in the value of knowledge has occurred since the economy moves to the centre of academic knowledge production; from priceless (i.e. knowledge as symbolic resource for humanity, independent of material benefits) to priced (i.e. knowledge as a commodified productive force in the global knowledge economy). They traced the history of this distinction to early twentieth century when Emile Durkheim coined the sacred/ profane dichotomy, then appropriated by Bernstein (2000) into conceptual/applied knowledge, and more recently discussed as symbolic/instrumental knowledge by Winch (2017). Inspired by these contrasting values of knowledge, we explore the possibility that the contemporary university is constituted as a sacred place where priceless knowledge is cultivated, rather than a corporation selling knowledge as a commodity. Within this constitution of the university, how might leadership and career look like? In what ways 
such alternative understandings on university leadership both enable and limit women in being a university leader? In this article, we discuss these possibilities with two Indonesian female deans, focusing on discourses given rise to their subjectivity as leaders.

Theoretically, this study employs a feminist poststructuralist framework, in which the cultivation of alternative subjectivities is seen as a form of agentic resistance to the operation of modern power (Foucault 1985; Weedon 1987). As modern power governs the society through the circulation of dominant discourses, individuals' capacity to draw on alternative discourses and give new meaning to experience may disrupt power's attempt to fixate certain meanings to the individual's sense of self or subjectivity (Weedon 1987; Willig 2013). In this study, we sought the ways in which the dominant discourse of neoliberal meritocracy - that has enjoyed a wide currency in giving meaning to contemporary academic career and university leadership - may be challenged by participants in the constitution of their subjectivity as a female university leader. More importantly, we focused on alternative discourses that participants have drawn upon and given rise to their sense of self as leaders, which in the current study includes discourses of spirituality and family. By identifying these alternative discourses, we hope that meritocracy as the dominant discourse in understanding academic career and university leadership may begin to be destabilised. Nevertheless, we are cognisant that - as Foucault (1978) has demonstrated - resistance is never outside of the operation of modern power itself. Power, in a Foucaultian sense, productively enables resistance and may even co-opt resistance into its omnipresent nexus of power relations. As unfolded in the Findings section, we also discussed the ways neoliberalism contextualises itself within or co-opts such local ways of thinking and being. Considering discursive formations in a society are always contextual, multiple, and shifting, the next section will briefly intro-

115 duce the context of this study, namely, Indonesian HE and its gender relations.

\section{Post-authoritarian Indonesia: women, leadership, and higher education}

Indonesia is generally considered as the world's third largest democracy while also containing the world's largest Muslim population - often hailed as the evidence that democracy and Islam is not antithetical (Barton 2010). Approximately 13 percent of the total number of Muslim population in the world live in Indonesia (Pringle 2010). Despite this Muslim majority, however, Indonesia does not constitute an Islamic state. While stating 'the belief in One Supreme God' as its first principle, the state ideology, Pancasila, is not based on one particular religion but upholding the virtue of Bhinneka Tunggal lka (unity in diversity). Although Indonesia is not an Islamic state, Islam does play a significant role in its socio-cultural-political-economic spheres, such as the mobilisation of religious identity politics during elections, the growth of halal industries, or - in the field of education - the presence of Islamic public universities in most major cities. Despite a recent surge in conservative Islamism (Schäfer 2019), historically, Indonesian Islam has been considered tolerant or 'moderate' (Burhani 2012). The largest and oldest Muslim mass organisation in the country, Nahdlatul Ulama (NU), for example, promotes and embodies the moderation of Islam in at least three principles, i.e. balance (al-tawazun), tolerance (altasamu), and justice (al-i'tidal) - including justice vis-a-vis gender relations. After the collapse of the New Order administration in 1998 which marked the birth of Indonesia's democracy, President Abdurrahman Wahid (1999-2001) who was also the chairman of 
NU (1984-1999) appointed 'the first truly feminist Minister for Women's Affairs' (Blackburn 2004, 107) and changed it into 'Ministry for Women's Empowerment' in 1999. What followed after the reform was ensuring that all policies became more gender aware.

In the political field, the provision of $30 \%$ candidate gender quota was implemented since 2004 to improve women's representation in parliament. Consequently, political parties proposed a steady increase in the proportion of women as candidates (Hillman 2017). Women's share of parliamentary seats has risen in two elections (2004 and 2009). According to Prihatini (2019) Islamic ideology does not limit female participation in legislative elections; it is institutional factors and political capital such as campaign funding that became the main challenges for women to advance in electoral politics (Hillman 2017; Prihatini 2019). In addition to the parliamentary quota, another achievement made in the political field is the appointment of 8 female ministers from 34 ministerial positions with strategic portfolios by the current President Joko Widodo in his first presidency period (2014-2019), although the number dropped to 5 in his second presidency (2019-2024). The strategic positions include Minister of Finance, Minister of Foreign Affairs, Minister of Maritime Affairs and Fisheries and Minister of State-Owned Enterprises. President Jokowi said in his keynote speech in the Women Congress on 6th April 2019, 'I believe in the greatness of women. I also believe their precision, perseverance and resilience' (Kumparan 2018).

While the development of women's empowerment in Indonesian politics is promising, progress in the HE sector has been slow (Dzuhayatin and Edwards 2010). The statistical overview on the gender imbalance in senior academic positions and leadership in Indonesian higher education sector is concerning. As per 2016, Indonesian higher education has 905 female professors and 3,864 male professors; 10,451 female senior lecturers and 20,038 male senior lecturers; 19,835 female lecturers and 29,523 male lecturers; and 20,930 female teaching assistants and 25,908 male teaching assistants (PDDIKTI 2016). While the lower academic positions (teaching assistant and lecturer) show a more balanced distribution between male and female academics, the top academic positions (senior lecturer and professor) show a glaring gap. The process of feminisation of labour 165 is evident in the preponderance of women occupying the 'basement' rather than the 'tower' of university structures (Fitzgerald 2012).

Despite this gap between gender, this decade has witnessed the emergence of women in the university leadership. The emergence of five female rectors in Indonesian public universities has marked a significant change in university leadership where it used to be the 'boys club' (Blackmore and Sawers 2015; Sakhiyya and Locke 2019). Women are considered as new subjects that enter into the masculine domain. Historically, in Indonesia women do not occupy this 'ivory tower' of senior management, where masculine values are reinforced such as prestige, esteem, individualism, competition, power and authority (Fitzgerald 2012). Rather, women sit on the place where the majority of university works such as administrative, emotional and relational work is carried out (Acker 2012); these positions are head of department and head of study programmes.

With 400 public and 4,246 higher education institutions (HEls), Indonesia's higher education is large as compared to most countries in the world. All these HEls have been subjected to rigorous audit regimes by Indonesian higher education accreditation body (BANPT), whose authority has been increasing in recent years (Wijaya Mulya 2016). For instance, any HEI missing the regular 5-year accreditation renewal for each of their study 
programmes cannot officially issue certificates to their graduates. The meticulous accreditation standards are generally market-driven and oriented towards world university rankings, such as institutional reputation, indexed publications, and the alignment between learning objectives and competencies needed in the workplace. Good university leadership is, thus, generally understood in terms of achieving these neoliberal and meritocratic criteria of success.

While women have increasingly taken up leadership positions in $\mathrm{HE}$, there is a dearth in the literature especially with respect to the neoliberalisation of HE. Blackmore $(2013,2017)$ argues that gender is the 'structuring structure' of the fast-moving neoliberal policies where academic workforce as well as leadership is feminised. Women make up most of administrative, relational and emotional labours in universities, while men dominate a more strategic, marketing, decision making and partnership spheres. Such division presupposes predetermined qualities of leadership that is masculine, goal-oriented, entrepreneurial, and competitive (Sakhiyya and Fitzgerald, in press; White Bagilhole, and Riordan 2012; Blackmore 2009). This applies not only in the Western universities but also in the Asian region where different cultural values, beliefs and ideological background influence how leadership is practiced and exercised. In studying Pakistan, Shah (2010) tenders a suggestion that theorising women leadership should be context-aware, as mainstream literature is embedded in Western philosophy and values. In Muslim societies like Pakistan and Indonesia where faith and daily practices should be integrated, the interplay between gender, leadership, and religion is under-researched.

Women leadership in HE is relatively an under-researched area not least because women are under-represented in university top management. Hitherto, there are only in the authors' best knowledge _ four scholarly articles on gender and HE in Indonesia. The first article focused on the challenges encountered by women in accessing senior leadership in HE. Dzuhayatin and Edwards (2010) believe that the challenges are culturally related and meritocracy is the solution. Secondly, Murniati (2012) studies challenges of career advancement faced by senior academic administrators in Indonesia and reveals that family supports, personal attributes, and policies contribute to women's career advancement into senior leadership positions. The third article, by Sakhiyya and Locke (2019), questions the taken-for-granted meritocracy and argues that there is a tension between meritocracy and empowerment discourses since empowerment works collectively and promotes gender equity, while meritocracy works individually by attributing achievement to one's distinction. Finallly, Sakhiyya and Fitzgerald (in press) argue that educational leadership in Indonesia needs to be approached critically by shifting the focus from locating women as the problem into the way leadership is constructed and enacted. This article builds on and extends these studies by - neither endorsing nor problematising meritocracy, but - exploring alternative discourses in constituting university leadership beyond meritocracy, as understood by female leaders in Indonesian universities.

\section{Methodology}

We selected two participants purposively, namely, women who occupy leadership positions in Indonesian universities. As we did not intend to use the data to generalise, but rather, to illustrate, we specifically approached female deans in our own universities 
and asked for their availability and consent to participate. Among the limited number of female deans in our universities, two responded and expressed willingness to participate. One was with a female dean at a public (secular) university in Central Java, and another one was with a female dean at a private (secular) university in East Java. We conducted audio-taped semi-structured interviews with each individual participant to provide spaces for them to explore relevant discourses in their leadership. To maintain a degree of confidentiality, we refer to them with pseudonyms (Hartini and Pratiwi) and their faculties are not stated in this article. The interviews took place in the participants' offices.

As younger faculty members, we were aware of and carefully and ethically navigated power dynamics in our relationship with participants. For example, while the interviews were conducted in Bahasa Indonesia, we customarily and intuitively included some polite local expressions typically spoken with older person/authority such as inggih (yes), which inevitably maintained relational hierarchy. As critical scholars raised in Indonesian religious families and educated in the West, during the analysis we were cognisant of the importance placed on religious and familial values in Indonesia, and how participant as a figure of authority and other Indonesian readers might feel about those values being assimilated - as we read it - into market-oriented agendas. Balancing between being contextually respectful and refusing to be crippled in our critical endeavour, we mindfully and fairmindedly interpreted the data as a complex interplay between resistance towards and reproduction of neoliberalism.

The interview data were analysed using Braun and Clarke's (2006) thematic analysis technique. After transcribing and familiarising ourselves with the data, we coded and then searched for, reviewed, and named the themes in the data. Guided by our research question, in these analytical processes we focused on underlying sets of interconnected ideas, or discourses, that have been drawn upon and given rise to participants' subjectivity as a female university leader.

\section{Findings}

\section{Leadership is amanah: constituting university leadership through a discourse of} spirituality

'Leadership is amanah.

If I have been given an amanah, I have to do my best wholeheartedly as a responsibility, as a commitment.'

Pratiwi

The first alternative discourse in constituting university leadership that might contest the dominant discourse of meritocracy is the understanding that considers structural or leadership position as amanah. Amanah is an Indonesian language adopted from Arabic language which means moral responsibility of fulfilling one's obligations in the name of God. When university is considered as a sacred place where priceless knowledge is cultivated, occupying senior academic and leadership position is seen as an amanah from God.

In Islam, (leadership) is amanah. If you are sure you can do it, do your best. For me, amanah is when I say 'yes', I will go all out to do my best. If not, then I betray the amanah according to my faith. So, when the Rector asked me to lead the faculty in 2011, I asked him: 'Do you think I can do this?' So, it's not about the salary - I don't have that kind of thought. Rather, it's about amanah. (Pratiwi) 
As Pratiwi explains above, it is God that holds the leaders accountable for what they have done in exercising the amanah and power. This understanding fundamentally challenges the neoliberal meritocracy's meta discourse of accountability which serves as a mechanism to control and monitor performance (Olssen and Peters 2005; Shore 2010). Under neoliberal governance, accountability is a disciplinary mechanism to create an efficient accountable system that can be standardised and disciplined. Within this neoliberal process of simultaneous control, academic works are centrally managed against quantifiable indicators so that their productivity and performance can be measured. This kind of accountability is primarily about control rather than professional integrity, and is actually based on a culture of mistrust rather than trust (Fitzgerald 2008); which can be counter-productive to organisational development.

Amanah could be a form of accountability that is empowering as well as restoring the culture of trust. Rather than maintained by external and instrumental disciplinary mechanisms, amanah is nurtured by internal motivations such as commitment, loyalty, and a sense of duty. The accountability is not only to stakeholders, beneficiaries and professional peers, let alone by performance assessment or external audits, but by spiritual values and faith. This discourse of amanah is widely circulating in Indonesian (Muslim) societies; even non-Muslims are familiar with this notion. During the interviews, both participants perceived the leadership positions they hold as amanah, something that combines commitment and integrity. Leadership is associated with responsibility and it is held accountable by and to God, instead of merely about (the game of) power and meritocracy. Therefore, when upholding amanah, one has to do it wholeheartedly. Our interview with Hartini illustrates this understanding:

Leadership position is amanah that brings about consequences in the forms of commitment and integrity. So, it is not easy to say yes to an amanah. But because the consequence is selfesteem, when I accept it, then I have got lots of things to do.

In another line of interview, Pratiwi said that she performed midnight prayers (sholat istikharoh) before making the decision for running the candidacy. She consulted her running for candidacy directly to God, not to the Rector.

Before making a decision, I always pray. I woke up mid night and pray, asking for the answer from God. I said, if this is the best according to You, grant me. But if it is not then it is not good for me and for the university. I always look for signs, and suddenly the signs came to me... That night I woke up around 2 AM where everyone was asleep. Afterwards, I wrote the vision and mission statement for running the candidacy.

When leadership is seen as a sacred matter, a God-trusted disposition, it may not go against the religious values and teachings. Leadership is, thus, an ethical issue. Within Islamic beliefs, the transcendental view of accountability, although it is held directly by God, consequentially manifests in human relationship. Like trust, amanah is a relational concept. As Codd (2004) argues, 'the trustworthiness of an individual not only benefits the person, but every other person with whom he or she interacts' (204). Trust grows more trust, and conversely mistrust breeds more mistrust. In an amanah framework, accountability does not separate such an ethical action from the very virtues that comprise professional life, in this case leadership. Our interviews resonate to such virtue. Pratiwi, for example, said that 'My silaturahmi - human to human relationship - will be better. 
Maintaining this relationship is important.' She added that 'not all amanah is in the form of leadership position', emphasising more on the virtue, rather than on the hierarchical structure and position she assumes.

Amanah enables a sense of dedication for something larger than the (capitalist) institution, namely, the people and/or the sacred knowledge. This stands in contrast to the neoliberal governance of meritocracy where leadership is dedicated to pave the way for accumulative and competitive entrepreneurial game for wealth, power, and prestige (Howson, Kandiko, and de St Croix 2018). Instead, amanah is more about devocation (dedication and devotion) to serve God.

The concept of amanah (trustworthy) is drawn from the elements of prophetic leader-

Q1 ship as practiced and modelled by Prophet Muhammad (Adz-Dzakiyaey 2005). The other three elements are siddiq (truthful), tabligh (deliver) and fathonah (wise and intelligent). Within Islamic belief, modelling the prophet's way of leadership is emphasised in the Qur'an. This kind of leadership emphasises the relationship between spirituality and leadership practices. However, as the nature of spirituality is intrinsic, internal, unquantifiable and un-measurable, there is a limit in drawing upon this discourse of amanah. It runs the risk of being manipulated and misused as merely rhetoric/cosmetics to suit the needs of the users (aspiring leaders) to gain people's trust and consequently secure the desired positions. This means that amanah is used politically and not spiritually. Meritocracy, in contrast, offers 'objective' instruments to quantify and measure talents and achievements. The 'objective' instruments, such as accountability and audit culture, are in place to replace 'trust' in the organisation. This has profound effects on universities, turning them from a place to cultivate priceless knowledge into/a place selling priced knowledge (Sakhiyya and Rata 2019).

Further, while drawing on Islamic discourse of amanah - on the one hand - may contest the logic and practices of neoliberal meritocracy, on the other hand participants' subjectivity as female leader in this study can also be seen as a form of neoliberal contextualisation within, assimilation into, or even co-optation of local socio-religio-cultural conditions. Studies on contemporary Islamic neoliberalism (e.g. Derichs 2017; Rudnyckyj 2009) 345 suggest that there is an increasing tendency of acceptance and appropriation of Western capitalist economy - such as in the growing trend of halal products, services, and industries in Muslim-majority countries - as opposed to Islamic anti-capitalist positions more predominant in the past. While contesting some aspects of neoliberal meritocracy in their leadership, both participants in this study evidently still pursued market-driven university rankings and accreditation status for their respective institutions. The common practice of saying bismillah (in the name of Allah) and prayers before submitting accreditation documents, for example, symbolises how neoliberal version of success is now a spiritual endeavour. Such narratives attest to the fluid and complex ways neoliberalism operates and travels all over the globe, where individuals, cultures, and societies may simultaneously adopt, reject, and modify neoliberal logics and sensibilities in different ways.

In sum, amanah is an alternative discourse that may potentially challenge the neoliberal meritocratic system by transcending accountability to God and instilling a culture of trust. While these trust and spiritually-oriented leadership may be mobilised to achieve marketdriven agendas, involving spirituality in approaching university leadership at least opens a space of alternative understanding what counts as leader. This leads to the next question: if leadership is amanah, then what counts as a university and how to lead a university? 


\section{Lead like a mother: university as family, leaders as parents}

'Surely, a human being is created by God.

And God is manifested in the world through our parents.'

Hartini

The second alternative discourse drawn upon by participants in understanding university leadership - which may contest the dominant discourse of meritocracy - is the notion of university as a family and leaders as parents. During the interviews, both participants analogised their workplace as a home or a family, and made repeated references to it. As illustrated by Hartini's words above, the institution of family ${ }^{1}$ in Indonesia is generally considered as sacred, because it is understood as initiated and established by God (e... Juwaini 2015); and therefore, parental authority are often positioned as the manifestation of divine authority. This section discusses the ways this discourse of university as a family enables an alternative subjectivity as a leader that may resist the dominant discourse of meritocracy.

In contrast with the nuances of objectivity, individualism, and competitiveness surrounding neoliberal meritocracy (Littler 2018), there is an atmosphere of relationality, togetherness, and harmony in participants' talk about their workplace and role as a leader. Pratiwi, for example, said that 'the faculty is like my second family ...I have friends who care... When I have problems, they helped me out.' Correspondingly, Hartini used 'a home' as a metaphor for her organisation:

In the faculty, I said to deputy deans, heads of departments, and student activists: This is our home. When this is our home, it is much more comfortable to lead because everyone is responsible. Everyone is a leader. Leader in their own field. I even said to the cleaning service: you are a leader. Leader in cleanliness and tidiness. This is called shared leadership. Hierarchy is needed, to determine the scope of responsibility, but all synergise. All should be wrapped in kekeluargaan.

In the neoliberal university, the high importance placed on university rankings and market pressures has made the power of top management and audit authorities rise, while the autonomy of the lower management decreases (Connell 2013); academic democracy has increasingly been undermined and superseded by the market mechanisms. The importance of trust and shared values, for example, decline in the face of neoliberal regime of meticulous audit and meritocratic reward system (Apple 2005). Drawing on the notion that the faculty is a home, Hartini is able to give meaning to her leadership in a way which might resist this neoliberally meritocratic regime. Instead of transactional, hierarchical, and audit-oriented, Hartini described her leadership style as collegial, or in her words, 'shared leadership' where everyone within the organisation is given the trust to be responsible with their work - a leadership style that is more common among women leaders (Goethals and Hoyt 2017). While Hartini does not oppose hierarchy, she quickly added a note that 'all should be wrapped in kekeluargaan' (translates as famili-ness) in order to mitigate negative ramifications of wide power distance typical in a hierarchical organisational structure. In Indonesia, the term kekeluargaan is generally used to express a form of relating to others like one's own family or relatives as opposed to formal/legal/transactional approach. This concept of kekeluargaan has been studied as an organisational culture in Indonesia (Wijaya Mulya, Mawardi, and Rahayu 2006) where family-inspired practices are encouraged at workplace, such as nurture, inter-dependence, 
and warm relationships. While the university structure still can be hierarchical, but at least power abuse, individualism, and high-handedness become less acceptable for practising leadership.

Understanding university leadership and academic career through a discourse of family also enables participants to disrupt the idea of individualism. Littler (2018) identifies that the most common image used to represent meritocracy is a ladder, where everyone is (supposedly) given an equal opportunity for upward social mobility. Since the opportunity is rendered as 'equally' provided, individuals tend to be blamed for their 'own' failures (Nielsen 2016). Besides ignoring unequal conditions in starting the climb, Littler (2018) 415 also points out that this image implies that success means individual success - a ladder is usually climbed alone. As opposed to meritocracy's individualism, both participants see that success means growing together harmoniously, there is no one-size-fits-all measure, and underperformers/troublemakers are nurtured and enabled like one's own family members, not fired. Pratiwi, for example, narrated:

A leader needs to be patient. Everyone walks on a different pace in their process of growth. I imagine myself as a conductor. Everyone plays a different instrument, a leader harmonises them. Everyone contributes in their own ways. Some lecturers like to do research, some develop the curriculum, and others deal with the accreditation standards.

I never see anyone as troublemakers or under-performers, they contribute in their own ways and I respect their contributions. Of course, as long as they don't disturb the whole team. Everyone has something to be developed, a potential; like the admin staffs, of which lecturers have complained a lot. Within their limitations, I see their high commitment. Their performance is still all right, I still can help them develop. Another example is a lecturer that was badly evaluated by students. I approach him personally, saying: here's the condition, why are you so emotional, what is your problem. He then openly told me about his personal problem, and I helped him. You see, everyone wants to be listened, to be treated humanely.

In understanding herself as a faculty leader, Pratiwi does not draw on the notions of objectivity nor merit-based approaches to individuals. Instead, she encouraged longterm growth by nurturing one's potential which could be different from each other. Connell (2013) noted that one major thing that is increasingly missing in the neoliberal university is nurture or pastoral care (Brabazon and Schulz 2018), which is essential for educational process. As the purpose of neoliberal higher education is narrowed into increasing one's employability by drilling competencies needed in the labour market, lecturers' ability to care, nurture, and response to the evolving needs of students may not be as important as the ability to respond to the evolving needs of quantified external indicators imposed by audit authorities and the market. Similar situations might apply for university leaders in their leadership, particularly in Indonesian contexts where most jobs at the university are still permanent/long-term instead of short-term/contract-based. Drawing on the discourse of university as a family, Pratiwi is able to put nurture at the centre of her practice as a leader. Like a mother, she showed care and nurture, focused on one's potential rather than weakness, and approached difficult people personally, listened, and built trust with them - keeping in her mind their (and the institution's) longterm development. As a result, throughout the interview Pratiwi expressed a sense of meaningfulness and satisfaction in nurturing and enabling growth, both in her faculty, her professional organisation, and regional association of deans, of which she was a leader. This sense of purpose in contributing to others/community is in contrast with 
the satisfaction of winning the competition for recognition, status, wealth, and money offered by neoliberal, meritocratic individualism (Littler 2018).

A critical question in this discussion is how a discourse of university as a family may offer an alternative to the notion of 'fairness' within the discourse of meritocracy? For instance, how can we think about fair career advancement and leadership appointment without relying on objectively-measured, merit-based criteria of excellence? While our interview data do not provide an answer to this specific question, there is a narrative from Pratiwi which might shed a glimpse of an alternative possibility to think differently about 'fairness':

There was this student came to me crying because she has no money to pay the tuition fee. Her father already passed away, and her mother is diagnosed with cancer. She works part time in our day care. I knew she is a good student. The rule says that she must drop out if she cannot pay. Period. But I imagined what if my daughter is in such a condition. So I negotiated with the vice rector, and gave her a concession so she can complete her degree. Rules are rules, but we don't have to follow them. Things are not black-and-white. It is much more important to be humane and follow our conscience.

What Pratiwi has done can be seen as unfair for other students who dropped out because they did not receive such special treatment. However, by imagining this struggling student as her own daughter, Pratiwi gave meaning to fairness - not as treating everyone in the same way or using the same objective measures but - as contingent on one's contextual situations. Guided by conscience and humanity, she considers rules as always negotiable. While previous researchers have demanded fairer and gender-sensitive criteria for lecturer/professor appointment and its consistent and transparent applications (e.g. Nielsen 2016; Brink and Yvonne 2012), we are concerned that there might always be other marginalised groups unfairly treated by any objective, merit-based criteria and mechanisms, such as various ethnic, religious, and sexual minorities. We propose that, to be able to negotiate the rule, guided by ethical reflexivity like Pratiwi did, might be more beneficial to respond to such complex situations than a consistent application of objective measures. We are cognisant that this proposal requires a sense of trust to the decision makers vis-à-vis their integrity and ethical commitment - which is frequently unavailable within the transactional contexts of the neoliberal university. However, constituting the university as a family might foster these practices of trust, communality, and ethical reflexivity as compared to the neoliberal, meritocratic view of the university.

It can be argued that Pratiwi's autonomy in negotiating the rules in this example is possible because this decision is not a high-stake decision, as in the appointment of a professor. While professorial appointment might indeed need more 'objective' criteria, Pratiwi offers an alternative, less-meritocratic view on career advancement towards professorship. Being a dean and a professor herself, Pratiwi does not see professorship ladder as the only career path for faculty members, because there are other options within academia, such as teaching, professional practice, and leadership positions. This is because in Indonesian teaching-oriented universities are still the default. It is only recently that higher education authorities gave a major pressure to shift to research-oriented universities for the sake of global academic competitiveness. Until now, teaching many courses still can generate reasonably good income for those focused on teaching. Money and good reputation as an expert can also be achieved by being an academic-practitioner working closely with 
business and industrial communities. The current rector in Pratiwi's university has not even completed his doctorate but he is seen as having extraordinary organisational and leadership abilities. This condition allows Pratiwi to focus on harmony and flexibility as a leader like in a family - not needing to impose one set of market-driven, meritocratic standards for all to achieve individually ('Some lecturers like to do research, some develop the curriculum, and others deal with the accreditation standards'). The situation is different from previous studies in Western countries (e.g. Locke and Wright 2017; Nielsen 2016; Brink and Yvonne 2012) where fair, objective, merit-based approaches are crucial for linear career advancement towards professorship, which then opens up opportunities for leadership roles.

Nevertheless, it is important to note that the notion of family drawn upon by participants to disrupt neoliberal meritocracy in our analysis is not unproblematic, as it is mainly understood from a traditional, gendered view on family, such as how relationality, emotionality, and harmony are ascribed to the mother's role. As Marxist feminists' now 510 classic criticism has pointed out, we might need to be very suspicious with the intimate relationship between capitalism and the (traditional) family, such as how women's unpaid domestic and emotional labours sustain both gender and class oppression. Privatisation and responsibilisation of family - both are important features of neoliberalism (Bond-Taylor 2016; Gillies 2014; Singer 1992) - further atomised individuals in the competitive society, keeping them busy pursuing financial security, personal happiness, successful career, and successful parenting; and away from political engagements. Fusing family-like relationship, care, and harmony into the workplace may be an effective way for neoliberalism to contextualise and assimilate into family-glorifying societies. While to some extent Hartini and Pratiwi's motherly-inspired leadership practices may provide alternatives to those of neoliberal meritocracy's, at another level they may also have paved the way for a more accepted version of neoliberal encroachment into the academia in Indonesia. Again, this demonstrates the flexible and polyvalent strategies of neoliberal governance and the complexity of the constitution of neoliberal subjectivity in the globalised world.

\section{Conclusion}

This article has argued that there are possibilities to disrupt the dominant discourse of neoliberal meritocracy in the constitution of participants' sense of self as a female university leader, although not without complexities and contradictions. How these Indonesian Muslim women construct their subjectivities as evident in the way they understand and define leadership is informed by the relevant cultural and belief systems - what it means to be a good Muslim as interpreted in Indonesian context. Their alternative subjectivities are enabled by other alternative discourses and their contextual situatedness, such as the discourse of 'leadership as amanah' and 'university as family' in an Indonesian context.

'Leadership as amanah', understanding leadership as a moral responsibility and held accountable by God, could potentially challenge meritocracy's discourse of accountability which serves as a disciplinary mechanism to control and monitor performance. 'Leadership as amanah' discourse transcends beyond the external and instrumental control of neoliberal reforms and cultivates the more fundamental elements of integrity and trust. University as family confronts the neoliberal's construction of university leadership that is 
transactional, hierarchical, and audit-oriented. Like a mother, women leaders show care and nurture, which is increasingly missing in the neoliberal university. This discourse gives a sense of purpose and places emphasis on the meaningfulness and satisfaction in nurturing and enabling growth of university staffs and academics, rather than instrumental and transactional way in managing university.

We have demonstrated the ways these discourses might serve as alternatives in giving new meaning to university leadership and academic career. Such alternative discourses are central to destabilise the predominant discourse of meritocracy, especially in the context of neoliberal governance, where merit is not merely understood as individual talent or achievement, rather an enterprising and self-promoting individual to pursue an endless entrepreneurial competitive game and success. We have also pointed out how these alternative discourses and subjectivities might not be completely unproblematic, such as the possibility of the neoliberal co-optation of such resistance. Even if our case is Indonesia, our argument that alternative local discourses and understandings of university leadership may challenge the dominant discourse of neoliberal meritocracy is transferrable outside of the Indonesian context according to contextual factors. Readers are advised to be reflexive in considering the transferability of this analysis. After all, the article is not intended to be an example to be followed, but to demonstrate that there is always hope and possibility to rework neoliberal meritocracy by drawing on available alternative discourses within the specific contextuality of our academia; but of course, without being overly hopeful.

\section{Note}

1. We are cognisant that the analysis here might be (mis)read as uncritically taking for granted the traditional (heteronormative, patriarchal) family institution. While here we draw on the notion of family to destabilise the neoliberal university, we also committedly support any critical endeavours to rework the traditional meanings of family.

\section{Disclosure statement}

No potential conflict of interest was reported by the author(s).

\section{Notes on contributors}

Teguh Wijaya Mulya is a lecturer in the Faculty of Psychology, University of Surabaya. He has a doctorate in education from the University of Auckland, New Zealand. Informed by feminism and poststructuralist theories, his research has been centred around the identification and destabilisation of dominant discourses in various domains, including higher education, gender, sexuality, and religion. His work has been published in journals such as International Journal for Academic Development, British Journal of Religious Education, Asian Studies Review, and Psychology and Sexuality.

Zulfa Sakhiyya is Assistant Professor at the English Department, Faculty of Languages and Arts, Universitas Negeri Semarang (State University of Semarang), Indonesia. Zulfa has had more than 10 years' experience in researching educational policies, discourse and gender in Indonesian context, and published in the area. Zulfa is currently a research fellow at the Centre for Innovation, Policy and Governance to assess knowledge production, diffusion and research policy-nexus in Indonesia. She was also a research fellow at Universities in Knowledge Economy (UNIKE), a four-year 
collaborative research project investigating the dynamic relationships between universities and knowledge economies in Europe and in the Asia-Pacific Rim funded by the European Commission.

\section{ORCID}

Teguh Wijaya Mulya (D) http://orcid.org/0000-0002-8899-1157

Zulfa Sakhiyya (D) http://orcid.org/0000-0003-4183-977X

\section{References}

Acker, Sandra. 2012. "Chairing and Caring: Gendered Dimensions of Leadership in Academe." Gender and Education 24 (4): 411-428. doi:10.1080/09540253.2011.628927.

Apple, Michael W. 2005. "Education, Markets, and an Audit Culture." Critical Quarterly 47 (1-2): 11-29. doi:10.1111/j.0011-1562.2005.00611.x.

Au, Wayne. 2016. "Meritocracy 2.0: High-Stakes, Standardized Testing as a Racial Project of Neoliberal Multiculturalism." Educational Policy 30 (1): 39-62. doi:10,1177/0895904815614916.

Bagilhole, Barbara, and Jackie Goode. 2001. "The Contradiction of the Myth of Individual Merit, and the Reality of a Patriarchal Support System in Academic Careers: A Feminist Investigation." European Journal of Women's Studies 8 (2): 161-180. doi:10.1177/135050680100800203.

Barton, Greg. 2010. "Indonesia: Legitimacy, Secular Democracy, and Islam." Politics \& Policy 38 (3): 471-496.

Bernstein, Basil. 2000. Pedagogy, Symbolic Control, and Identity: Theory, Research, Critique. Lanham, MD: Rowman \& Littlefield.

Blackburn, Susan. 2004. Women and the State in Modern Indonesia. Cambridge: Cambridge University Press.

Blackmore, Jill. 2009. "Globalisation, Transnational Feminism and Educational Justice." In Race, Ethnicity and Gender in Education: Cross-Cultural Understandings, edited by Joseph Zajda, and Kassie Freeman, 3-30. Houten, Netherlands: Springer Netherlands.

Blackmore, Jill. 2013. "A Feminist Critical Perspective on Educational Leadership." International Journal of Leadership in Education: Theory and Practice 16 (2): 139-154. doi:10.1080/13603124. 2012.754057.

Blackmore, Jill. 2017. "Leadership in Higher Education: A Critical Feminist Perspective on Global Restructuring." In Death of the Public University: Uncertain Futures for Higher Education in the Knowledge Economy, edited by Susan Wright, and Cris Shore, 90-113. Oxford: Berghahn Books.

Blackmore, Jill, and Naarah Sawers. 2015. "Executive Power and Scaled-up Gender Subtexts in Australian Entrepreneurial Universities." Gender and Education 27 (3): 320-337. doi:10.1080/ 09540253.2015.1027670.

Bond-Taylor, Sue. 2016. "Domestic Surveillance and the Troubled Families Programme: Understanding Relationality and Constraint in the Homes of Multiply Disadvantaged Families." People, Place and Policy 10 (3): 207-224. doi:10.3351/ppp.0010.0003.0003.

Brabazon, Tara, and Sam Schulz. 2018. "Braving the Bull: Women, Mentoring and Leadership in Higher Education." Gender and Education (November): 1-18. doi:10.1080/09540253.2018.1544362.

Braun, Virginia, and Victoria Clarke. 2006. "Using Thematic Analysis in Psychology." Qualitative Research in Psychology 3 (2): 77-101. doi:10.1191/1478088706qp063oa.

Brink, Marieke van den, and Benschop. Yvonne. 2012. "Gender Practices in the Construction of Academic Excellence: Sheep with Five Legs." Organization 19 (4): 507-524. doi:10.1177/ 1350508411414293.

Burhani, Ahmad Najib. 2012. "At-Tawassut Wal I'tidal: The NU and Moderatism in Indonesian Islam." Asian Journal of Social Science 40: 564-581. doi:10.1163/15685314-12341262.

Carli, Linda L. 2015. "Women and Leadership." In Handbook of Gendered Careers in Management: Getting In, Getting On, Getting Out, edited by Adelina M. Broadbridge, and Sandra L. Fielden, 290-304. Cheltenham, UK: Edward Elgar Publishing. 
Codd, John. 2004. "Export Education and the Commercialisation of Public Education in New Zealand." New Zealand Annual Review of Education 13: 21-41.

Connell, Raewyn. 2013. "The Neoliberal Cascade and Education: An Essay on the Market Agenda and Its Consequences." Critical Studies in Education 54 (2): 99-112. doi:10.1080/17508487.2013.776990.

Derichs, Claudia. 2017. Knowledge Production, Area Studies and Global Cooperation. London: Routledge.

Dzuhayatin, Siti Ruhaini, and Jan Edwards. 2010. “Hitting Our Heads on the Glass Ceiling: Women and Leadership in Education in Indonesia." Studia Islamika: Indonesian Journal for Islamic Studies 17 (2): 199-232.

Fitzgerald, Tanya. 2008. "The Continuing Politics of Mistrust: Performance Management and the Erosion of Professional Work Erosion of Professional Work." Journal of Educational Administration and History 40 (2): 113-128. doi:10.1080/00220620802210871.

Fitzgerald, Tanya. 2012. "Ivory Basements and Ivory Towers." In Hard Labour?: Academic Work and the Changing Landscape of Higher Education, edited by Tanya Fitzgerald, Julie White, and Helen M Gunter, 7, 113-135. UK: Emerald Group Publishing Limited. doi:10.1108/S1479-3628 (2012)0000007007.

Foucault, Michel. 1985. The History of Sexuality, Vol. 2: The Use of Pleasure. New York: Pantheon Books. Gillies, Val. 2014. "Troubling Families." In Thatcher's Grandchildren?, edited by Stephen Wagg, and Jane Pilcher, 204-224. London: Palgrave Macmillan UK. doi:10.1057/9781137281555_11.

Gipson, Asha N., Danielle L. Pfaff, David B. Mendelsohn, Lauren T. Catenacci, and W. Warner Burke. 2017. "Women and Leadership: Selection, Development, Leadership Style, and Performance." The Journal of Applied Behavioral Science 53 (1): 32-65. doi:10.1177/0021886316687247.

Goethals, George R., and Crystal L. Hoyt. 2017. Women and Leadership: History, Theories, and Case Studies. Great Barrington, MA: Berkshire Publishing Group.

Hillman, Ben. 2017. "The Limits of Gender Quotas: Women's Parliamentary Representation in Indonesia." Journal of Contemporary Asia 48 (2): 322-338. doi:10.1080/00472336.2017.1368092.

Howson, Camille B, Kelly Coate Kandiko, and Tania de St Croix. 2018. "Mid-Career Academic Women and the Prestige Economy." Higher Education Research \& Development 37 (3): 533-548. doi:10. 1080/07294360.2017.1411337.

Johnson, Heather L. 2017. "Pipelines, Pathways, and Institutional Leadership: An Update on the Status of Women in Higher Education." Report. American Council on Education. https:// vtechworks.lib.vt.edu/handle/10919/84062.

Juwaini, Jazuli. 2015. "Ketahanan Keluarga." Republika. June 30, 2015. https://www.republika.co.id/ berita/koran/urbana/15/06/30/nqqwsl39-ketahanan-keluarga.

660 Kumparan. 2018. "Jokowi Kagumi Menteri Wanita: Bu Susi Galak, Bu Retno Pantang Mundur." Kumparan.com, October 24.

Littler, Jo. 2018. Against Meritocracy: Culture, Power and Myths of Mobility. London: Routledge.

Locke, Kirsten, and Susan Wright. 2017. "Mainlining the Motherboard : Exploring Gendered Academic Labour in the University." In Gender, Governance and Feminist Analysis. doi:10.4324/ 9781315561509-4.

665 Murniati, Cecilia T. 2012. "Career Advancement of Women Senior Academic Administrators in Indonesia: Supports and Challenges. "Doctoral thesis, The University of lowa. https://ir.uiowa. edu/cgi/viewcontent.cgi?article=3416\&context=etd.

Nielsen, Mathias W. 2016. "Limits to Meritocracy? Gender in Academic Recruitment and Promotion Processes." Science and Public Policy 43 (3): 386-399. doi:10.1093/scipol/scv052.

Nikunen, Minna. 2012. "Changing University Work, Freedom, Flexibility and Family." Studies in Higher Education 37 (6): 713-729. doi:10.1080/03075079.2010.542453.

Olssen, Mark, and Michael Peters. 2005. "Neoliberalism, Higher Education and the Knowledge Economy: From the Free Market to Knowledge Capitalism." Journal of Education Policy 20 (March 2015): 313-345. doi:10.1080/02680930500108718.

PDDIKTI. 2016. "Statistics of Academic Positions in Indonesian Higher Education by Gender." 2016. https://forlap.ristekdikti.go.id/files/infografis.

Prihatini, Ella S. 2019. "Islam, Parties, and Women's Political Nomination in Indonesia." Politics \& Gender, 1-23. doi:10.1017/S1743923X19000321. 
Pringle, Robert. 2010. Understanding Islam in Indonesia: Politics and Diversity. Singapore: Mainland Press Ltd.

Rudnyckyj, Daromir. 2009. "Spiritual Economies: Islam and Neoliberalism in Contemporary Indonesia." Cultural Anthropology 24 (1): 104-141. doi:10.1111/j.1548-1360.2009.00028.x.

Sakhiyya, Zulfa, and Tanya Fitzgerald. In press. "Critical Perspectives in and Approaches to Educational Leadership in Indonesia." In Understanding Educational Leadership: Critical Perspectives and Approaches, edited by Steven J. Courtney, Helen M. Gunter, Richard Niesche,

Q2 and Tina Trujillo. London: Bloomsbury Academic.

L Sakhiyya, Zulfa, and Kirsten Locke. 2019. “Empowerment vs. Meritocracy Discourses in Indonesian Public Universities: The Case of Female Leaders." Asian Journal of Women's Studies 25 (2): 198216. doi:10.1080/12259276.2019.1610210.

Sakhiyya, Zulfa, and Elizabeth Rata. 2019. "'From 'Priceless' to 'Priced': The Value of Knowledge in Higher Education." Globalisation." Societies and Education 17 (3): 285-295. doi:10.1080/ 14767724.2019.1583089.

Schäfer, Saskia. 2019. "Democratic Decline in Indonesia: The Role of Religious Authorities." Pacific Affairs 92 (2): 235-255. doi:10.5509/2019922235.

Scully, Maureen A. 1997. "Meritocracy." In Blackwell Encyclopedic Dictionary of Business Ethics, edited Q3 by Patricia Hogue Werhane, and R. Edward Freeman. Oxford, UK: Wiley-Blackwell.

L Shah, Saeeda J. A. 2010. "Re-thinking Educational Leadership: Exploring the Impact of Cultural and Belief Systems." International Journal of Leadership in Education 13 (1): 27-44. doi:10.1080/ 13603120903244879.

Shore, Cris. 2010. "Beyond the Multiversity: Neoliberalism and the Rise of the Schizophrenic University." Social Anthropology 18 (1): 15-29. doi:10.1111/j.1469-8676.2009.00094.x.

Singer, Jana B. 1992. "The Privatization of Family Law." Wisconsin Law Review 1992: 1443.

Weedon, Chris. 1987. Feminist Practice \& Poststructuralist Theory. Oxford: Blackwell.

White, Kate, Barbara Bagilhole, and Sarah Riordan. 2012. "The Gendered Shaping of University Leadership in Australia, South Africa and the United Kingdom." Higher Education Quarterly 66 (3): 293-307. doi:10.1111/j.1468-2273.2012.00523.x.

Wijaya Mulya, Teguh. 2016. "Neoliberalism Within Psychology Higher Education in Indonesia: A Critical Analysis." ANIMA Indonesian Psychological Journal 32 (1): 1-11.

Wijaya Mulya, Teguh. 2019. "Contesting the Neoliberalisation of Higher Education Through StudentFaculty Partnership." International Journal for Academic Development 24 (1): 86-90. doi:10.1080/ 1360144X.2018.1520110.

Wijaya Mulya, Teguh, Artiawati Mawardi, and Yusti Probowati Rahayu. 2006. "Memahami Kekeluargaan Sebagai Budaya Organisasi Di Indonesia." Anima Indonesian Psychological Journal 21 (3): 260-274.

Willig, Carla. 2013. Introducing Qualitative Research in Psychology. Berkshire, UK: McGraw-Hill Education.

Winch, Christopher. 2017. Teachers' Know-How: A Philosophical Investigation. Hoboken: Wiley. 